\title{
Environmental projects as a pillar economic growth
}

\author{
Marija Todorović \\ Faculty of organisational sciences \\ University of Belgrade \\ Belgrade, Republic of Serbia \\ marija.todorovic@fon.bg.ac.rs
}

\begin{abstract}
The paper presents the significance of environmental projects for economic growth and society. The paper deals with the basic characteristics of environmental projects and project management based on systematic literature review, and presents the current state of project management for environment protection at the local level in the Republic of Serbia, as a result of empirical research. The main findings showed that different measures need to be taken aiming to have more project applications at the local level in field of environment protection and to improve project management practice that jointly can contribute the economic growth. Based on the main findings, the paper also provides recommendations on improving environmental project management at the local level in Serbia.
\end{abstract}

\section{Keywords—environment, projects, economic growth}

\section{INTRODUCTION}

Environmental protection policy and legislative has been recognized not just as a necessity and as a cost but as an investment and the opportunity to enhance economic growth [1,2]. To recognize the long term effect of environment protection projects on other systems and to harmonize environmental, economic and social aspects, global environmental politics has changed into sustainable development politics. Typical environment protection projects are dedicated to waste management, air pollution, water quality, hygiene practices, renewable energy, biodiversity etc. These projects should contribute to a better quality of life, increased number of saved lives, increased citizen empowerment, economic growth (e.g. agriculture, traffic and tourism development), and employment. Recognizing all multiple effects, the focus of this paper is on the contribution of the environmental projects to the local development and economic growth.

\section{ENVIRONMENTAL PROJECTS}

\section{A. The complexity of projects for environment protection}

Projects for environment protection are considered as very complex, mainly due to next characteristics:

- Ownership - environmental projects are mainly owned by public institutions, with a monopoly position at the market $[3,4]$.

- Complex stakeholder management - these projects have a number of different stakeholders (central and local government, service providers, national legislative, donors [4]. This further implicates the importance of stakeholder management $[5,6]$.

- Legislative - Law, contracts, agreements with donors and other partners, procedures [4].

- Dependence - Environmental projects have been mainly the part of a program which requires the commitment to program objectives and frequently the dependency on other projects [7].

\section{B. Impact on economic growth}

Environmental projects can influence the economy at the local and at the national level, e.g. project for biodiversity could lead to tourism development and the incensement of tourism revenue. Tourism development can create the necessity for infrastructure projects (roads and hotel capacity). Due to this connection with other sectors and multiple effects, these projects should be part of the local or national strategic management plan [8].

According to [9] the application of a new polices in the area of environmental protection requires expert knowledge which can be further used to leverage company's core competencies, increase market share and reduce costs due to resource efficiency.

The nowadays focus on environment protection and new global and local environmental regulation can be seen as a new opportunity for companies that would not otherwise perform these activities. From 90 s in XX century many developed countries have started to implement circular economy concept to harmonize humanity and nature, social and economic aspects (among the first countries in the world that emphasize circular economy is China) [10]. In Europe we have good circular economy practice in - German and Sweden [11,12]. Hart [2] have provided a profound study to explain the relationship between environmental regulation and technological innovation. The author confirms that new regulation imply additional activities, application of expertise, but if a company uses the technology boom in a smart way, the innovative solution can be created and bring more value for customers.

Environment protection project can contribute to economic growth constructing the platform for a green economy, increased employment and new jobs 
$[9,13]$. In terms of new jobs, the above-mentioned authors refer to "green" jobs, "as jobs that contribute to the reduction of the environmental impact of enterprises and economic sectors towards sustainable levels" [13]. Besides these jobs, the percentage of employment can be increased as a consequence of new open jobs on environment projects implementation, and other sectors development.

We stated multiplicand effects on other sectors, benefits for companies and to individuals through new jobs; still it is important to state the importance and the effects of natural environment protection. The natural environment can enable economic growth through, e.g. waste decomposition where naturally occurring micro-organisms provide benefits through their ability to break down organic matter and speed up this process. In addition, some ecological processes provide benefits through the storage, processing, and acquisition of nutrients essential for plant growth.

The impact on the economy can also be seen through cost-benefit analysis [14]. According to this analysis, we can find benefits in reducing negative impact on, e.g. people's health and value it in money. Based on WHO data ref "The effects of outdoor air pollution on our respiratory and cardiovascular systems are estimated to between 12,000 and 24,000 premature deaths every year. It is estimated to reduce overall life expectancy by up to 7-8 months per person and cost the UK $£ 20.5$ billion per year" [15].

Every action that provides value creation and/or cost (or any other negative impact) can be seen as a contribution to economic growth.

Besides the direct impact on economic growth, environmental projects have impact and provide value for:

- People employed on projects - working on these mainly donor-funded projects project, people can gain knowledge about the procedures, project planning, organization and reporting and expert knowledge for specific industry $[16,17,18]$.

- Society - program goal is dedicated not only to environment protection but on economy and attitudes of society $[3,6,19]$.

- Policymaking - Implemented projects can compromise future policy goals and initiate policy changes in terms of better regulation of environment protection [20].

- Future projects - Good project management can influence future project [20].

\section{Environmental project management}

Project management is the application of tools and techniques, skills, knowledge and experience to achieve specific project objectives through project initiation, planning, implementation, monitoring and control $[21,22,23]$.To manage environmental projects, the knowledge about environmental issues, pollution causes, protection measures, as well as the project background, is necessary [24].

The initiation phase of project management should be supported with the research of environmental issues, communication with key institutions for environment protection, ensuring compliance with the environmental regulation and procedures. As stated in the introduction, environmental projects are mainly funded by donors or government. In both cases the procedures of initiating, planning, leading, monitoring and reporting processes need to be provided according to required procedure [4]. This phase also requires the problem analysis, stakeholder analysis, business case (project background) and project objectives and scope [21]

Further, in the project planning phase, it is crucial to obtain core team (researches, scientists), equipment, data and other relevant resources, to define project schedule, resource plan and the budget. Project implementation is focused on leading people, change management risk management and stakeholder management. During the implementation phase, project monitoring should be conducted according to previously defined key performance indicators and have the reporting system. [25].

The research provided on the project management implementation in public sector emphasizes the importance of the national culture and other social factors, as well as the administration and the economy [26]. Further, the project management success depends on project governance, an appropriate project management approach and project manager competence $[17,25]$

To initiate projects, to improve the practice of project management and create social welfare, different measures are necessary: legislative, support in terms of information, finance, standards, best practice $[5,12,17,25,26,27]$.

\section{RESEARCH METHODOLOGY}

The main purpose of the empirical research was to investigate the project processes, tools and techniques applied in the field of environment protection. The empirical research was conducted in the Republic of Serbia, targeting the key actors on environmental projects.

The research techniques used were a questionnaire based on literature review and previously conducted desk research of available national and local documents, supported structured interviews.

\section{A. Sample description}

Officers for environment protection at the local level are in $74.5 \%$ women, with an average age of 45 . Almost $20 \%$ of the respondents have experience of 
managing projects, $80 \%$ have the experience as a core team member or a project associate. No one has formal education or certificate for project management.

\section{B. Research results}

Results have shown that the weakest part of the environment project management process is the initiation and project monitoring and control. On the Likert scale from 1-5 the average grade for the project initiation is 3.29 and for project monitoring 3.31. Project initiation is directly related to the strategic documents at the local level (strategic priorities, local action planes and the budget) [21].

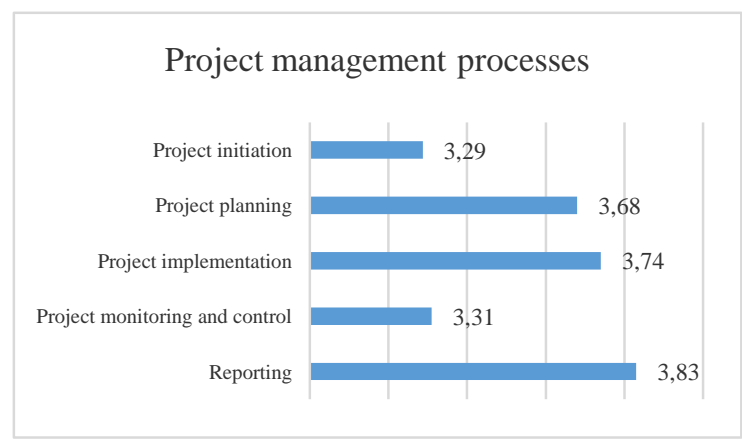

Fig. 1. Implementation of project management processes

Through desk research available national and local strategic documents and national document [28] we found three issues related to strategic documents: lack of legislative to make strategy implementation obligatory; second, there is no standard procedure of strategy monitoring and evaluation; third, the quality of strategic documents is not at the same level within municipalities.

If we combine desk and empirical research results, the causes of the poor implementation of project initiation process can be recognized as a system problem.

Even when the project planning and reporting have higher grades, one can conclude that the project management processes application can be improved (Fig. 1).

Statistics show that the number self-initiated projects especially funded by donors is very small. The part of the questionnaire was dedicated to the types of projects implemented. Summary results showed that projects in most of the cases are related to legal obligation (e.g. waste management that is legal obligation for all municipalities). Projects referring to air pollution or biodiversity are at the bottom of the list.

To clarify the causes of the current state, the structured interviews were conducted. Questions were based on literature review [4,24,29,30]. After processing and analyzing data we have classified the answers in three categories:

\section{1) Individual level}

Local government officials need continuous support. Technical support in developing project proposals to meet donor's criteria and procedures and information support. All participants agreed that one of the prerequisite to initiate a project and develop a project proposal is related to the available summarized information about donors, open calls of Ministries and other financial sources.

Local government officials need Continuous professional development: continuous education in terms of getting knowledge in the field of environment protection (legislative, standards, etc.) as well updated and improved knowledge on project management.

\section{2) Organizational level}

One of the key challenges at the organizational level is the lack of project management methodology and the responsibility assignment during the project implementation.

\section{3) Institutional level}

At the institutional level, the weaknesses are: the allocation of responsibility, commitment of the decision-makers, strategic consistency, communication at the local level and the lack of recognition of projects as an additional work that should have an adequate reward.

Based on the interview results, the next question was dedicated to respondents opinion on what kind of the support at the institutional level is needed to initiate a larger number of projects and to manage project better (Fig 2). Almost all respondents gave the highest impact on commitment of the local authorities.

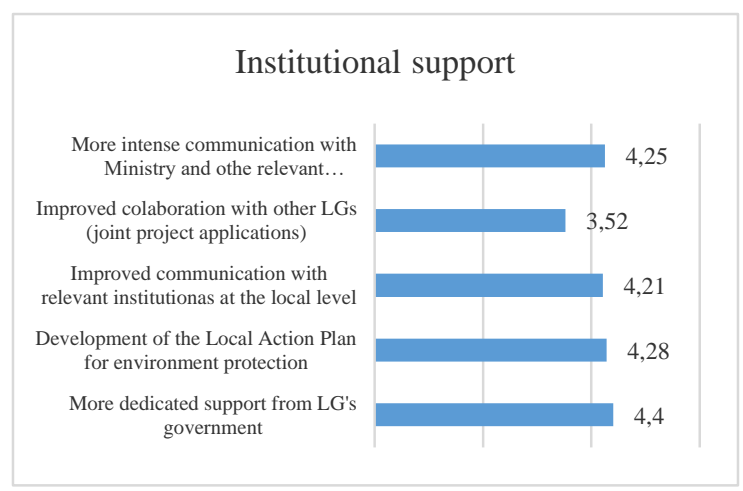

Fig. 2. Institutional support to initiate projects and manage projects

Through the interviews, we came to the conclusion that, among the different areas and priorities at the local level, environment protection is not recognized as a pillar for economic growth. Further, the strategic documents at the local level should be improvement in terms of quality and in terms of recognizing environment as a source of social and economic development and supported wit 
action plans. Comparing the empirical research we can conclude that the cooperation with other municipalities and joint applications are not recognized as a source of support project proposals development and project management [30]. This is contrary to the [31] where one of the most important drivers for environment projects is the cooperation at the local level. Further, the authors emphasize publicprivate partnership for sustainable process industry.

The next question aimed to define which elements related to the work of employees would support project initiation and project management (Fig. 3). The respondents gave a slight advantage to professional education and training above the information of open calls for project application and availability of strategic documents from the national level. Although every support is necessary (Fig. 3).

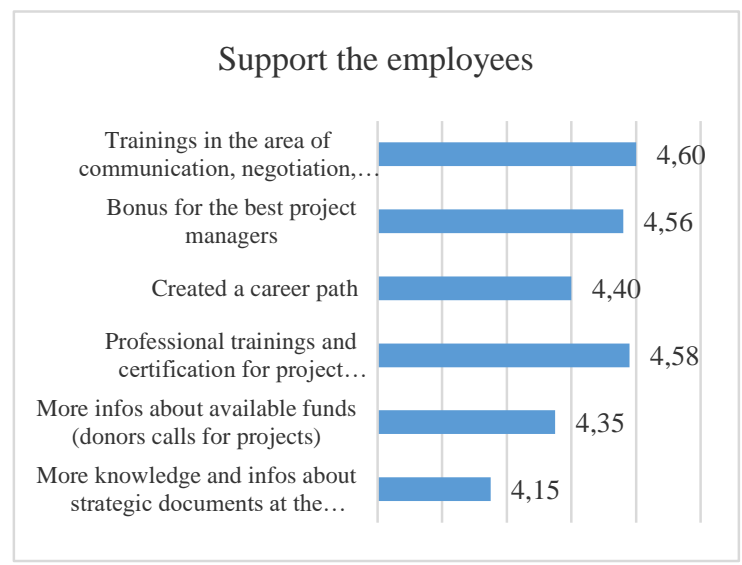

Fig. 3. Support the work of employees

The authors further aimed to identify key areas of knowledge that will enable project initiation and improve the project. People who were project managers listed Teamwork, Communication and Resource and cost management as a crucial area of knowledge and skills that enable project management. Core team members and project's associates selected Teamwork, Resource and cost management, Project monitoring and reporting as a top three areas. Based on the results it can be concluded that the teamwork is in the intersection for both categories.

\section{CONCLUSION}

The paper emphasizes the importance of environmental projects for social and econ1omic growth. The research was located in the Republic of Serbia and has provided key measures to be taken in order to: initiate more environment protection projects to create economic growth and to improve project management and use these projects. Key findings of the research conducted are that project management needs to be improved on different levels. The environment protection goals should be incorporated into sustainable development goals $[4,9,32,33]$ and stated in strategic documents and action plans that will enable the strategy implementation and exact project definition. Further steps refer to project management approach that should be fitted to cultural, economic and administrative system. This support would create a good environment to initiate environmental projects to become the pillar of economic growth and sustainable development of a society and further, to improve project management.

The commitment of local authorities to environment protection and more intensive communication with key stakeholders (especially central and local government) are emphasized. Still, networking with other municipalities is not recognized as a driver for better project management and opportunity for a joint application.

The next recommendation refers to people although technical skill and knowledge is crucial for project management, research results showed that local government officials need the improvement of behavioural skills (teamwork and communication skills). The respondents showed that gaining behavioural and technical knowledge and skills are certainly needed that confirms the previous research conducted.

These improvements will build institutional and individual capacities to cope with the existing and new requirements for environment protection and to new opportunities for economic growth.

\section{ACKNOWLEDGEMENT}

This paper is a result of the Project No. 179081 funded by Ministry of Education and Science of the Republic of Serbia: Researching Contemporary Tendencies of Strategic Management Using Specialized Management Disciplines in Function of Competitiveness of Serbian Economy.

\section{REFERENCE}

[1] R. C., Feiock, C. Stream, "Environmental Protection Versus Economic Development: A False Trade-Off?" Public administration review, 61(3), pp. 313-321, 2001.

[2] D. Hart, "When Does Environmental Regulation Stimulate Technological Innovation?" Information Technology and Innovation Foundation, 2018.

[3] C. J. Igbokwe-Ibeto, "Issues and challenges in local government project monitoring and evaluation in Nigeria: The way forward." European Scientific Journal, ESJ, 8(18), 2012.

[4] V. Santos, J. Varajão, "PMO as a Key Ingredient of Public Sector Projects' Success", Position Paper. In Procedia Computer Science, Elsevier B.V., Vol. 64, pp. 1190-1199, 2015.

[5] H. Bulkeley, "Reconfiguring environmental governance: Towards a politics of scales and networks." Political Geography, 24(8), pp. 875-902, 2005.

[6] M. Hall, R. Holt, "UK public sector Project management-a cultural perspective." Public Performance \& Management Review, 25(3), pp. 298-312, 2002.

[7] L. Istrate, L. Marian, I. S. Ferencz,, "The Use of a Project Management Application in Managing Investments in a Public Administration Institution" Procedia Economics and Finance, 15, pp. 1732-1739, 2014. 
[8] H. Tallis, P. Kareiva, M. Marvier, A. Chang, "An Ecosystem Services Framework to Support Both Practical Conservation and Economic Development", Proceedings of of the National academy of Sciences of the United States of America 2008, 105(28), 2008.

[9] K. Hyun Woo, H. Jae-Kak, P. Jin-hee, "Green Growth and Green Jobs in Korea: Potentials and Perspectives", Friedrich Ebeng Stiftung, Energy\&Climate Policy Institute, 2012.

[10] Z. Yuan, J. Bi, Y. Moriguichi, "The Circular Economy: A New Development Strategy in China", Journal of industria ecology, Yale school of forestry \& Environmental studies, 10(2), pp. 4-8, 2008.

[11] G. Schiller, F. Müller, R. Ortlepp, "Mapping the anthropogenic stock in Germany: Metabolic evidence for a circular economy", Resources, Conservation and Recycling, 123, pp. 93-107. 2017.

[12] Y. Kalmykova, M. Sadagopan, L. Rosado. "Circular economy-From review of theories and practices to development of implementation tools." Resources, Conservation and Recycling. 135, pp. 190-201, 2018.

[13] B. Bartniczak, M. Ptak, "Green jobs in the renewable energy sector”, Ordnungspolitische Diskurse, No. 2015-01, Ordnungs Politisches Portal, 2015.

[14] C.R. Sunstein, "Cost-benefit analysis and the environment." Ethics 115.2 pp. 351-385, 2005.

[15] Interdepartmental Group on Costs and Benefits, Air Quality Subject Group, Department of Environment, Food and Rural Affairs in partnership with the Scottish Executive, Welsh Assembly Government and Department of Environment Northern Ireland 2007.

[16] M. Barber, S. Jackson, J. Shellberg, Sinnamon,V. "Working Knowledge: characterising collective indigenous, scientific, and local knowledge about the ecology, hydrology and geomorphology of Oriners Station, Cape York Peninsula, Australia”, The Rangeland Journal, 36(1), pp. 53-66, 2014.

[17] B. Jałocha, H. P., Krane, A. Ekambaram, G. PrawelskaSkrzypek, G. "Key Competences of Public Sector Project Managers", Procedia - Social and Behavioral Sciences, 119, 247-256. 2014

[18] J. Brooks, K. A., Waylen, M. B. Mulder, "Assessing community-based conservation projects: a systematic review and multilevel analysis of attitudinal, behavioral, ecological, and economic outcomes", Environmental Evidence, 2(1), 2013.

[19] Z. Savić, Z. Bogetić, M. Dobrota, N. Petrović, "A Multivariate Approach in Measurement of the Sustainable Development of European Countries", Management: Journal of Sustainable Business and Management Solutions in Emerging Economies. 21(78), pp. 73-86, 2016.

[20] M. C. Thompson, M. E. R. Baruah, Carr, "Seeing REDD+ as a project of environmental governance", Environmental science \& policy, 14(2), pp. 100-110, 2011.

[21] European Commision, "PM2 Project Management Methodology", Centre of Excellence in Project Management (CoEPM), 2018.

[22] IPMA "Individual Competence Baseline for Project, Programme and Portfolio Management", International Project Management Assotiation, 2015.

[23] PMI, "Gide $t$ the Project Management Body of Knowledge", Sixth Edition, Project Management Institute, 2017.

[24] G. Y. Abbasi, H. Al-Mharmah, "Project management practice by the public sector in a developing country", International Journal of Project Management, 18(2), pp. 105-109, 2000.

[25] D. Bourguignon, Closing the loop, new circular economy package, European Parlament Research Service, 2016.

[26] L. C. Stuckenbruck, A. Zomorrodian, "Project management: the promise for developing countries", International Journal of Project Management, 5(3), pp. 167-175., 1987.

[27] M. Todorović, V. Obradović, "Sustainability in project management: a project manager's perspective" Sustainable Growth and development in small open economies, editors, I. Ljumović, A Elteto, pp. 88-107, 2018.
[28] V. Kopanja, I. Teodorović, Z. Njegovan, "Analiza procesa planiranja u gradovima i opština u Republici Srbiji”, Stalna konferencija gradova i opština, 2013.

[29] Wirick, D. (2009). Public-sector project management: meeting the challenges and achieving results. John Wiley \& Sons.

[30] V. Obradović, M. Todorović, M. Jovanović, "Environmental Project Management: Contextual Enablers and Boundaries", 31 st IPMA World Congress 2019 "Integrating sustainability into project management", 2019 (accapted for publishing)

[31] Spalek, S. (2014). The Influence of Country of Origin on Project Management: An International Empirical Study. Procedia - Social and Behavioral Sciences, 156, 4-7.

[32] J. Katainen, C. Moedas "The circular economy - connectiong economic and environmental gains", European Commission, 2017.

[33] N. Petrović, I. Bošnjak, S. Nedeljković, "Disaster risk reduction for sustainable development goals", European Project Management Journal, 7(2), pp. 27-35, 2017. 